\title{
Some remarks about the development of views on the origin of the foehn
}

\author{
JULIUS HANN
}

\author{
Original citation: \\ HANN, J., 1885: Einige Bemerkungen zur Entwickelungs-Geschichte der Ansichten über den Ursprung des Föhn. - \\ Meteorol. Z. 2, 393-399. \\ Suggested citation: \\ HANN, J., 1885: Einige Bemerkungen zur Entwickelungs-Geschichte der Ansichten über den Ursprung des Föhn (Some \\ remarks about the development of views on the origin of the foehn). - Meteorol. Z. 2, 393-399 (translated and edited by \\ VOLKEN, E. and S. BRÖNNIMANN. - Meteorol. Z. 21 (2012), 591-596)
}

\begin{abstract}
This is the translated and edited version of the article „Einige Bemerkungen zur Entwickelungs-Geschichte der Ansichten über den Ursprung des Föhn" (Some remarks about the development of views on the origin of the foehn) by JULIUS HANN. The paper was originally published in the Meteorologische Zeitschrift 2, 393-399.
\end{abstract}

Keywords: Julius Hann, foehn, classic paper.

Superscript numbers indicate original footnotes (translated at the bottom of the page), E... numbers indicate editorial endnotes (at the end of the article), square brackets [ ] indicate editorial comments in the text.

Certainly it does not dishonour our time that history becomes increasingly important and appreciated in the natural sciences. This is also the case in meteorology where it shows in the ambition for complete bibliographies. HELLMANN's most famous work is one of the most pleasant fruit of this endeavour ${ }^{\mathrm{E} 1}$. Even the works of researchers of earlier periods are increasingly being read nowadays and their results are brought back to attention.

Therefore, I should also be allowed to cover some pages in this journal with some notes about the development of the view on an interesting problem of recent meteorology. The cause to do so is the presentation by Prof. W. VON BEZOLD ${ }^{\mathrm{E}}$ at the annual meeting of the German Meteorological Society in Munich, which has been published in this journal, and in particular the passage that deals with the importance of the correct view on the origin of the foehn, which is attributed to the famous physicist HERM. v. HELMHOLTZ ${ }^{\mathrm{E} 3}$.

Several years ago (1881), when I first reviewed the works by JAMES P. ESPY ${ }^{\mathrm{E} 4}$ : Philosophy of Storms (Boston 1841) ${ }^{\mathrm{E} 5}$ and the Fourth Meteorological Report (Washington 1857$)^{\mathrm{E} 6}$ more thoroughly (I confess this with humiliation), I realized with astonishment that this excellent meteorologist, who is still not honoured accordingly, has published a large number of the theorems that we nowadays consider as achievements of "modern meteorology". He did not simply provide incoherent thoughts, which is hardly of any value in the natural sciences, but a proper physical theory which can be verified on the basis of observations.

The statements about the temperature decrease in rising air streams due to expansion, the time lag of this temperature decrease in humid rising air streams due to the released latent heat of the water ${ }^{1}$, the heating of sinking air streams due to the compression taking place, the formation of precipitation due to upward movement of air, with a remark on the inadequacy of the rain theory by HUTTON $^{\mathrm{E} 7}$, the impossibility of rain and cloud formation in sinking air streams and therefore the rejection of the view that rain in the temperate zones is to be attributed to the water vapour content of the "upper trade wind", the dryness of the air in the areas of barometric maxima, and in particular in those of the subtropical areas, the cause for the daily periodicity of wind velocities and various other things ${ }^{2}$ can be found in these works. The statements are formulated as findings according to true physical principles, which can also be verified and confirmed on the basis of meteorological observations.

Here, we would like to emphasize in the first instance that ESPY was in possession of the newer theory about the foehn and clearly pronounced it. I may be allowed

${ }^{1}$ ESPY determined the amount of the temperature decrease as well as the conditions for cloud formation by means of an apparatus invented by himself, which he called nepheloscope.

${ }^{2}$ I will not go into detail regarding those statements on the theory of storms since these are the only ones that have found a wider acceptance. 
some short citations (partly condensed) from the "Fourth Meteorological Report. February 1857"E6, however, a larger part of these sentences can be found in the book Philosophy of Storms, $1841^{\mathrm{E} 5}$, that is, they go much further back than the relevant publications by HELMHOLTZ $^{\mathrm{E} 3}$ considered here ${ }^{\mathrm{E} 8}$.

I inferred from the great rains on the west of the Rocky mountains that, in consequence of the great quantity of latent caloric evolved by the condensation of vapor there and carried over the mountains by the air, it was probable that the mean temperature near the mountains on the east side would be found to be abnormally great, and such it has been found to be (p. 52).

ESPY commented the statement that in Las Palmas ${ }^{\mathrm{E} 9}$, on the north-eastern side of Gran Canaria, October was the warmest month, whereas in $\mathrm{S}$. Cruz ${ }^{\mathrm{E} 9}$, on the southern side of Tenerife, it was August:

If it shall be found, on examination, that great rains fall on the south side of Canary Island in October the latent caloric evolved into the upper air on the north side of the island will account for this high temperature (p. 53).

It is known that air in passing over high mountains such as the Himalaya or the Andes, is 20 or 30 degrees warmer than the atmosphere is at the same height over plains, because of passing over them it has the latent caloric in it, just evolved by the condensation of the vapor on the windward side, making it ten degrees warmer for every tenth of an inch of elastic vapor condensed than it would be in rising to the same height without vapor in it to condense. (p. 146.)

In this way ESPY explained the high temperature and dryness of the scirocco ${ }^{\mathrm{E} 10}$ in Palermo ${ }^{\mathrm{E9}}$ (p. 200), and the high temperature of the north-western winds on the eastern side of the Rocky Mountains in the northwest of Canada, p. 147. (Evidently, Espy makes the mistake of trying to explain all hot winds, also the Simoom ${ }^{\text {E11 }}$ etc., in this way.)

The theory, also, would indicate that during the great rains that take place north of the head of the Golf of Venice ${ }^{\mathrm{E} 9}$, and south of the Carnic Alps ${ }^{\mathrm{E} 9}$, there would be felt on the north slope of these Alps a very hot, dry wind, such as the sirocco is described to be (p.153).

The only thing that misses here is the term foehn, the correct theory is described clearly. Without knowing it, I provided a special proof exactly for this sentence by ESPY in my essay "Über den Föhn und sein Auftreten

\footnotetext{
${ }^{3}$ By the way, by the beginning of this century, the Swiss natural scientist EBEL ${ }^{\mathrm{E} 13}$ already was on the right track for finding the true foehn theory. "Due to the remark that the Alpine crest often represented a boundary regarding the weather, he considered the Alps as the origin of the foehn; its high temperature was caused by the heat released when the vapour turns into drops. In the notes of the "Naturforschende Gesellschaft" [Natural Sciences Society] Zurich (II. Vol. 24) ${ }^{\mathrm{E} 14}$, specific proofs are given for this." I have taken this paragraph from DovE's publication: Über Eiszeit, Föhn und Scirocco [About ice age, foehn and sirocco], p. 29-30 (Berlin 1867) ${ }^{\mathrm{E} 15}$. It is peculiar how one can have the truth right under one's nose and not seeing it! At that time, DovE's thinking was already influenced by preconceived theories to such an extent that he valued natural phenomena only as far as they agreed with the theories.
}

in the Ostalpen" ${ }^{\text {E12 }}$ [About the foehn and its occurrence in the eastern Alps]; Jahrbuch des deutsch-österreichischen Alpenvereins 1879), as well as in the Zeitschrift [der österreichischen Gesellschaft] für Meteorologie (Vol. VIII. p.10).

There can therefore be no doubt that ESPY has known the correct physical theory about the foehn since at least the beginning of the fifties. That he did not or rather could not relate it to the mechanical theory of heat goes without saying. ${ }^{3}$

I may be allowed to add some other principles proposed by ESPY that belong to "modern meteorology", which, however, are only distantly related to the foehn theory.

\$ 68. It is stated in the books, and seems to be the general opinion, that the upper trade wind carries with it an immense quantity of vapor, to produce rains in high latitudes. But this cannot be the fact, for the air, before it rises over the equatorial regions, condenses nearly all its vapor into cloud, and therefore, when it rises above the cloud and rolls off to higher latitudes, it carries with it but little vapor etc.

In a comment it is then emphasized that HUMBOLDT $^{\mathrm{E} 15}$ found the driest air near the northern borders of the trade wind.

This dryness of the air near the northern borders of the trade wind, no doubt, is produced by the descending currents of the air in those regions, where the barometer stands above the mean. ( $p$. 55.)

It is thaught also, that this upper trade wind, when it reaches higher latitudes, produces rain in its descent to the surface of the earth. But this cannot be, for if the air were to descend from the upper regions to lower, it would be able to contain below, merely from the heat of compression, at least four times as much vapor as it contained above, even if it had been before saturated. So far then, from this upper trade wind prodning clouds when it descends, it causes the air to be extremely dry (p. 56.)

$\$ 70$. Clouds cannot be formed in this manner - that is, by descending masses of cold air.

In $\S 84$, this is discussed more in detail.

Wherever there is an ascending column, there will be cloud, and all around it where the air is descending it will be perfectly clear (p. 109.).

These statements may suffice to prove that ESPY had almost reached the level of knowledge of so-called "modern meteorology". The only thing to which he paid little attention was the influence of earth rotation on atmospheric movements. ${ }^{4}$ To a considerable extent, ESPY's findings had to be re-established again against preconceptions which remained almost generally accepted for a long time.

\footnotetext{
${ }^{4}$ Cf. p. $218-219$ of the Fourth Report ${ }^{\mathrm{E} 7}$. I may point at the passage which contains an anticipation of the so-called convective equilibrium of the atmosphere: $\$ 122$. From these observations and experiments alone, I am justified in using in my calculations the datum ,that equal weighto of air at all heights in the normal state contain equal quantities of caloric nearly."
} 
In 1852, Dove discussed the temperature conditions in ascending and descending air masses without referring to the foehn, but fully aware of the physical principles underlying them. In his paper "Die Verbreitung der Wärme auf der Oberfläche der Erde" [The distribution of heat at the surface of the earth ${ }^{\mathrm{E} 16}$, it is written on p. 3-4: "The motion of air which has been heated by the contact with the ground is confronted by the same force in all horizontal directions, however, the force is smaller upwards than downwards. Thus, it rises and cools down with increasing expansion [Auflockerung], since it cannot keep the same temperature when thinning with the heat taken from it in its dense state [da die im dichten $\mathrm{Zu}$ stand entnommene Wärme sie bei ihrer Verdünnung nicht mehr bei derselben Temperatur zu erhalten vermag]. This is why the temperature decreases with height. If the temperature decrease was only due to the thinning, an air mass, wrapped in a compact elastic shell and thrown from the peak of a high mountain into the valley, would increase its temperature in parallel to the increase in density, so that it would always have the temperature of the atmospheric layer that it passes through. On the other hand, a horizontally lying air parcel of one mile length and therefore filled with warm dense air would extend to a length of ten miles when being erected, but cool down to such an extent that the air at its upper end would have the same temperature as the atmosphere has at that distance from the earth. However, the cooling is smaller in reality which is a result of the water vapour ascending simultaneously with the warming air."

From this, it is obvious that Dove was quite aware of the so-called convective equilibrium of the atmosphere it seems strange that he did not make any use of it. However, DOVE was different before the mid-fifties than later on, far less constricted by his own theories. It can hardly be denied that DOVE's entirely unphysical theories impeded the progress of meteorology for a long time.

Now, I would like to tie in with VON BEZOLD's lecture ${ }^{\mathrm{E} 2}$, namely with the phrase "that it was my studies about the foehn that first supported the new insights (namely those by VON HELMHOLTZ) and then caused them to become known in the narrow circle of meteorological research".

A lecture whose task was to present "the progresses of scientific meteorology in the course of the last decades" to a larger public within about an hour has, of course, to condense the single statements very much. However, this brevity can easily give cause for the misunderstanding of a sentence here and there. This could also have been the case with the statement just mentioned, and thus, I allow myself to explain the issue in more detail and thereby to make another contribution to the history of the foehn problem.

The statement by Prof. v. BEZOLD cited above could easily be interpreted to suggest that after the lecture given by Prof. v. HELMHOLTZ and its publication ${ }^{\mathrm{E} 3}$, the larger public or at least the representatives of the natural scientific disciplines accepted the new doctrine immediately with the exception of the meteorologists who ignored it and had to be convinced of its correctness by later studies. This was indeed not the case, apart from what I have said before with regard to ESPY. The short paragraph in VON HELMHOLTZ' lecture "Über Eis und Gletscher" ["About ice and glaciers"] ${ }^{\mathrm{E} 3}$ which is related to the foehn, does not seem to have been of any impact regarding the foehn problem, probably because for the larger scientific public as well as for the physicists in a narrower sense, the foehn problem did not exist. Thus, they were not particularly receptive to that paragraph. For the meteorologists, on the other hand, who may have read the lecture, the reference was too short and too general to motivate them to develop a foehn theory. One has to consider that a single general sentence included in a larger popular science lecture may hardly ever have a particular impact. Primarily, however, one has to consider what the dispute about the origin of the foehn was about. The contentious issue was not the warmth of the foehn, since DOVE did not deny it and could explain it with his theory, but its dryness. The Swiss natural scientists related the dryness to the Sahara ${ }^{\mathrm{E} 9}$, which (seemingly) was in strongest contrast to DOVE's view that the foehn was the descended upper trade wind. Since, according to Dove, the foehn reveals "its origin, the warm Caribbean Sea" by causing very intensive precipitation. DOVE went as far as to doubt the correctness of the observations made at the Swiss meteorological stations, and this was the main reason for the fierceness and the personal bitterness in the dispute about the origin of the foehn, which, otherwise, would be entirely inexplicable. DOVE as an all-powerful authority on the one side, whom almost all non-Swiss natural scientists trusted blindly, and some Swiss natural scientists on the other side, whose main weapon were the results of the observations at their newly founded meteorological stations. And then, the all-powerful opponent, superior in authority and supporters, challenged the evidentiary value of these observations; he even hinted at a suspicion of deliberate deceit. This had to cause a culmination of the dispute. Since, at that stage, the foehn problem dealt mainly with the explanation of the dryness of the foehn which was not mentioned in Prof. v. HELMHOLTZ' lecture, none of the parties to the dispute referred to it, and therefore, it could not make any contribution to clarify the problem and to settle the dispute. It had already been assumed by DOVE that the descending air of the equatorial stream was heated, but he would not go into the physical causes for this phenomenon at all or even develop its further consequences. ${ }^{5}$

At this stage, I published an article about the origin of the foehn in the first volume of the Zeitschrift der Österreichischen Gesellschaft für Meteorologie in October $1866^{\mathrm{E} 18}$. In this article, the dryness of the foehn was related to the warming of the descending air of the

\footnotetext{
${ }^{5}$ POISSON's equation ${ }^{\mathrm{E} 17}$ according to which pressure and temperature of an air mass change, had been known for a long time, and there was no lack of experiments to apply it to the conditions of the free atmosphere.
} 
"equatorial stream"6. The air must be relatively humid at elevated heights, but arrives relatively dry at the ground. I then pointed out - and this seemed to me of utmost importance with regard to the dispute - that even Greenland had its foehn which could certainly not originate in the Sahara.

I still believe that this had been the crucial step for rejecting the Sahara theory of the foehn, and I continued to make an effort to collect evidence that almost any mountain range has its foehn and published them in longer and shorter articles. The next step was that WILD and I showed that there is also a foehn on the southern side of the Alps which then comes from the north. The evidence that foehn phenomena are of a general nature and must originate in the mountain ranges themselves probably contributed most to the gradual acceptance of the "physical foehn theory". It is likely that the theory itself would not have succeeded as quickly as that.

In my essay "Der Föhn in den österr. Alpen" [,,The foehn in the Austrian Alps“" ${ }^{\mathrm{E} 19}$ - (Zeitschrift für Meteorologie. II. Volume, October 1867, namely p. 440 ff.), one can find the physical foehn theory rather comprehensively developed for the first time and compared with observations. Independently, WILD published soon afterwards the essay "Über Föhn und Eiszeit" ["About the foehn and the ice age"], rector's lecture, held on 15 November 1867 (Bern 1868) $^{\mathrm{E} 20}$. In this lecture, the southern foehn in the northern Alps is causally related to the Atlantic barometric depression for the first time, and the existence of the northern foehn on the southern Alps is pointed out. The explanation of the dryness of the foehn directly refers to my first essay (October $1866)^{\mathrm{E} 18}$, and it is stated that this essay eliminated the difficulty of finding a reason for the mysterious changes of the southern winds after having passed the Alpine crest (p. 26). With the publication by WILD in combination with the publications previously mentioned, the foehn problem was brought to an end in some respects.

Only for the sake of completeness, the papers will be mentioned here:

DOVE: Über Eiszeit, Föhn und Scirocco [About ice age, foehn and scirocco]. Berlin $1867^{\mathrm{E} 15}$.

DovE: Der Schweizer Föhn [The Swiss foehn] (addition to the previous publication). Berlin $1868^{\mathrm{E} 21}$.

WILD: Der Schweizer Föhn. Entgegnung. [The Swiss foehn. Reply]. Bern $1868^{\mathrm{E} 22}$.

A classic work about the occurrence of the foehn has been written by M. L. DUFOUR: "Recherches sur le Foehn du 23. September 1866 en Suisse" [Study about the foehn of the 23 September 1866 in Switzerland]. Bull. de la Soc. vaudoise. Vol. IX. $1868^{\mathrm{E} 23}$.

It represents the best monograph available about the occurrence of the foehn in Switzerland. However, the theory is mentioned only by referring to other works. MüHRY's deserving essay "Über den Föhnwind" [About

${ }^{6}$ At that time, I was still strongly influenced by DOVE's theories, which were slowly rejected and replaced by independent thinking later. the foehn wind], Zeitschrift für Meteorologie. Vol. II, $385^{\mathrm{E} 24}$ and the notes about a map sketch of a foehn wind (ibidem Vol. III, 363) ${ }^{\mathrm{E} 25}$ belong into the same category. The nature of the foehn phenomena and their local boundaries are represented according to the observations of the Swiss meteorological network.

The reading of a paper by $\mathrm{B}$. DüRER about his observations at Villa Carlotta [near Tremezzo] ${ }^{\mathrm{E} 9}$ at lake Como and his remarks about a warm dry northerly wind caused me to examine this northern wind, which DüRER called scirocco, more closely. I did so in my essay "Der Scirocco der Südalpen" [The scirocco of the southern Alps], Zeitschrift für Meteorologie. III. Vol. December $1868^{\mathrm{E} 26}$. There, it was shown that this wind is a true foehn, the appearance of which is restricted to the mountains, namely to some southern Alpine valleys only. ${ }^{7}$ First, I could prove an important fact with regard to the foehn theory, namely that in the case of northern foehn, on the southern side of the Alps, the temperature decrease with height is almost precisely $1{ }^{\circ} \mathrm{C}$ per $100 \mathrm{~m}$. This corresponds exactly to the theory of the warming of descending air masses. On the northern side, however, the temperature decrease is hardly half of that amount. In the case of southern foehn, the conditions are vice versa, so that on the lee side, where the air descends, the temperature decrease with height is almost $1{ }^{\circ} \mathrm{C}$ per $100 \mathrm{~m}$, whereas on the windward side, where the humid air rises, the temperature decrease with height is only about $0.5^{\circ} \mathrm{C}$ per $100 \mathrm{~m}$. Hence, the foehn phenomenon had finally been related to the mechanical theory of heat. Later, I have filled a small gap in the theory of the foehn in my essay: "Der Föhn in Bludenz" [The foehn in Bludenz ${ }^{\mathrm{E9}}$ ] (Sitzungsberichte der Wiener Akademie. Märzheft 1882 [Proceedings of the Imperial Academy of Sciences in Vienna]) ${ }^{\mathrm{E} 28}$.

In the further use of the thermodynamic theory of the foehn ${ }^{8}$, I myself as well as my successors have emphasized too much on the sentence that the high temperature of the descending air stream on the lee side of a mountain range depended on the condensation heat of the water vapour, which would precipitate in the form of rain or snow on the windward side of the mountain range. It is, however, a fact that the foehn occurs in northern Switzerland ${ }^{\mathrm{E} 9}$ before precipitation starts on the southern side. This was also the case for the foehn event on the 23 September 1866 described by DUFOUR ${ }^{\text {E23}}$, which he particularly emphasizes. This could justly have been used as an objection to our foehn theory.

In the essay cited I have shown that given the normal temperature decrease with height, any quickly descending air mass has to result in a foehn wind. ${ }^{9}$ Therefore,

${ }^{7}$ BILLWILLER provided further evidence in the essay: Über ein lokales Auftreten des Nordföhns - [About a local occurrence of the northern foehn] Zeitschrift [der österr. Ges] für Met. Vol. X. ${ }^{\text {E27 }}$

${ }^{8}$ The important essay by Capt. N. HOMEYER: Föhn in Grönland [The foehn in Greenland] should also be considered. ${ }^{\mathrm{E} 29}$

${ }^{9}$ Alternatively, the heat of the air mass could be said to result in part from previous condensation processes. 
a directly preceding rainfall on the southern side of the Alps is not necessary to explain the high temperature of the first foehn gusts. With the continuation of the foehn, the air masses located further back will also be set into motion. Then, precipitation begins on the southern side which is the reason why the heating of the descending air masses on the other side continues. The temperature decrease with altitude is smallest in winter and fastest in summer, which explains the relatively larger temperature increase for winter foehn. Based on a remark made by BILLWILLER ${ }^{\mathrm{E} 27}$, the mechanical process for the descending of the foehn will also be attempted to be explained.

The statements made here demonstrate that the development of the foehn theory took a similar course as the discovery of the true causes of many natural phenomena. Various natural scientists had already had the correct ideas for a long time, but they could not find general acceptance as long as the discipline concerned had not generally progressed far enough to offer a fertile ground to these ideas for being further developed. Furthermore, the knowledge of the facts, i.e., observations regarding the phenomenon, had to be sufficiently numerous and sound enough in order to test the theory so thoroughly that all other hypothesis could be ruled out, and that the results predicted by the theory could indeed be found at a certain place and as forecasted.

\section{Endnotes}

E1 Gustav Hellmann, German meteorologist (18541939), known for his work on meteorological observations (e.g., pluviometric observations) and history of meteorology. The work cited here most likely is:

HellmanN, G. 1883: Repertorium der Deutschen Meteorologie. - W. Engelmann, Leipzig, 995 pp. (http:// www.dmg-ev.de/fachausschuesse/fagem/neueSeite/ Hellmann.htm)

E2 JOHANN FRIEDRICH WILHELM VON BEZOLD (18371907), German meteorologist and atmospheric thermodynamicist, 1885-1907 director of the Prussian Institute of Meteorology at the University of Berlin. He worked on (and indeed introduced the concepts of) potential temperature, equivalent temperature and pseudo-adiabatic processes.

BEZOLD, W. V. 1885: Über die Fortschritte der wissenschaftlichen Witterungskunde während der letzten Jahrzehnte. - Meteorol. Z 2, 313-324.

E3 HelmholtZ, H., 1865: Eis und Gletscher: Vorlesung gehalten im Februar 1865 in Frankfurt a. M. und Heidelberg. - In: Populäre wissenschaftliche Vorträge von H. Helmholtz, Vol.1, Vieweg und Sohn, Braunschweig, 93-134.

E4 JAMES POLLARD ESPY, 1785-1860, American meteorologist and one of the first to use the telegraph for collecting meteorological observations. ESPY served as a meteorologist with the U.S. War Department and the U.S. Navy until 1852, when he continued his work at the Smithsonian Institution, Washington, D.C.

(James Pollard Espy. Encyclopædia Britannica. Encyclopædia Britannica Online Academic Edition. Encyclopædia Britannica Inc., 2012. Web. 24 Oct. 2012.)

E5 EsPy, J.P., 1841: Philosophy of Storms. - Boston. (available from eBooksRead.com) Note that in HANN's paper there is a typo (the publication year is given as 1871)

E6 EsPY, J.P. 1857: Fourth Meteorological Report. Washington. $240 \mathrm{pp}$.

E7 JAMES HUTTON, 1726-1797, Scottish geologist known for the concepts of plutonism and uniformitarianism.

HutTON, J., 1788: The theory of rain. Transactions of the Royal Society of Edinburgh 1(2), 41-86.

E8 The quotes were in English in the original paper, highlighted in italics.

E9 Map of the locations mentioned in the paper

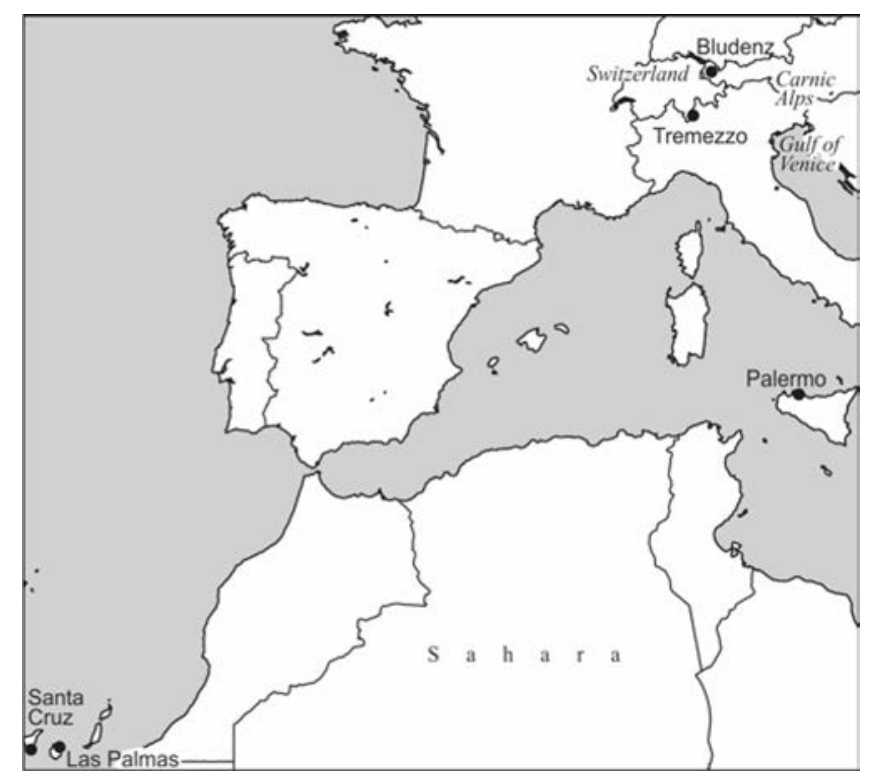

E10 Scirocco is the name for a hot and dry southerly or southeasterly, often stormy wind from the Sahara towards the Mediterranean.

E11 Simoom is a hot, suffocating and dust-laden wind in the Sahara and the Middle East.

E12 HANN, J., 1879: Über den Föhn und sein Auftreten in den Ostalpen. - Jahrbuch des deutsch-österreichischen Alpenvereins 10, 175-179.

E13 JOHANN GOTTFRIED EBEL, 1764-1830, Swiss scientist and author of a popular travel book on Switzerland. The original reference is not given (Dove, in the same text, writes ,... .nach den von EBEL gesammelten Notizen").

E14 The quote is arguably referring to the following publication, which however was not available to us:

DENZLER, H. H., 1848: Ueber die Erscheinungszeiten und die Erkennung des Föhns in der Schweiz. - Mitth. Natf. Ges. Zürich 2(24), 17-28.

E15 Dove, W: 1867: Über Eiszeit, Föhn und Scirocco. - D. Reimer, Berlin, 116 pp. 
E16 Dove, W. 1852. Die Verbreitung der Wärme auf der Oberfläche der Erde. - D. Reimer, Berlin, 26 pp.

E17 SIMÉON DENIS POISSON, 1781-1840, French mathematician and physicist. The Poisson equations define adiabatic paths in the state space of an ideal gas:

$p \cdot v^{\eta}=$ constant,

where $\eta=c_{p} / c_{v}$, i.e., the ratio between specific heat capacity at constant pressure and the specific heat capacity at constant volume.

POISSON, S.D., 1823: Sur la chaleur des gaz et des vapeurs. - Ann. Chim. Phys. 7, 319-392.

E18 HANN, J., 1866: Zur Frage über den Ursprung des Föhn. - Z. österr. Ges. f. Meteorol. 1(17), 257-263.

E19 HANN, J., 1867: Der Föhn in den österreichischen Alpen. - Z. österr. Ges. f. Meteorol. 2(19), 433-445.

E20 WILD, H. 1867: Über Föhn und Eiszeit. Rektoratsrede gehalten am 15. November 1867 in Bern. - Bern.

E21 DovE: H. W., 1868: Der Schweizer Fön: Nachtrag zu "Eiszeit, Föhn und Scirocco". - D. Reimer, Berlin.

E22 WILD, H. 1868: Über Föhn und Eiszeit, mit Nachtrag: Der Schweizer Föhn. Entgegnung auf Dove's gleichnamige Schrift. - Zeitschr. f. schweiz. Stat., Bern, 1868.
E23 Dufour, M. L., 1868: Recherches sur le Foehn du 23 September 1866 en Suisse. - Bull. de la Soc. Vaudoise. Sci. Nat. 9(58), 84 pp.

E24 MÜHRY, A. 1867: Über den Föhnwind. - Z. österr. Ges. f. Meteorol. 2, 385-397.

E25 MüHRY, A. 1868: Kartenskizze eines Föhnwindes. - Z. österr. Ges. f. Meteorol. 3, 363.

E26 HANN, J., 1868: Der Scirocco der Südalpen. - Z. österr. Ges. f. Meteorol. 3, 257-263.

E27 BiLlwiller, R., 1875: Über ein lokales Auftreten des Nordföhns. - Z. österr. Ges. f. Meteorol. 10(22).

E28 HanN, J., 1882: Über den Föhn in Bludenz. - In: Sitzungsberichte der Kaiserlichen Akademie der Wissenschaften, Mathematisch-naturwissenschaftliche Classe, 85, 416-440.

E29 HOFFMAYER, W., 1878: Le Foehn du Groenland (review). - Z. österr. Ges. f. Meteorol. 13, 65, 70 (citation from HanN, J., 1908: Handbuch der Klimatologie. Third Edition. - Stuttgart, Engelhorn.) 